\title{
Problems Identification of DFI Village Jakhani: A Participatory Approach
}

\author{
Diksha Patel $^{1}$, Shyam Singh ${ }^{2 *}$, S. C. Singh ${ }^{1}$ and Manjul Pandey ${ }^{1}$ \\ Krishi Vigyan Kendra, Banda, Universiy of Agriculture and Technology, \\ Banda-210001 (U. P.), India \\ *Corresponding author
}

\section{A B S T R A C T}

\section{Keywords \\ DFI, Focus group discussion, \\ Participatory Rural Appraisal, Problem identification, FPO}

\section{Article Info}

Accepted: 05 April 2020 Available Online: 10 May 2020
The present study was undertaken at Krishi Vigyan Kendra, Banda, Uttar Pradesh where Jakhani village has been selected for doubling farmers income by 2022. A total of 50 respondents were selected randomly who were engaged in agriculture and allied activities. Data were collected through focus group discussion, Participatory Rural Appraisal and a semi-structured interview schedule. The problem identification technique was used to identify and prioritize the problems related to agriculture and allied sectors in the village. The result of study revealed that nearly half of the respondents $(46.00 \%)$ were belongs to old aged category. Majority of respondents $(88.00 \%)$ were male, had high experience category $(66.00 \%)$ and more than half of respondents $(54.00 \%)$ were having low level of annual income category. The result of problem identification technique revealed that crop losses due to Anna pratha, getting less price for their produce (Pusa basmati-1121) and poor yield of major crops (Rice and wheat) were the most prioritized problems of farmers of Jakhani village with RBQ value $94.59,90.41$ and 71.66 respectively. The policy makers of state animal husbandry department can develop plan for breed improvement and should also promote organic farming by use of cow dung and urine to control the anna pratha. Farmers should be motivated to use National Agriculture Market (e-NAM) and Farmer Producer Organisation (FPO) platform for marketing of their farm produce to fetch better price for agriculture produce. Timely sowing, judicial use of fertilizer and appropriate use of planting techniques should be adopted by farmers for getting better yield of major crops.

\section{Introduction}

Agriculture is one of the most important pillar of the Indian economy. The contribution of agriculture and its allied sectors to India's GDP stood at $15.4 \%$ during 2018-19 (Government of India, 2019). More than half of the country's population is directly or indirectly dependent on agriculture and allied sectors for its subsistence. India's food production multiplied about more than threefold times while population multiplied two and half fold. Due to this, India not only becomes food self-sufficient but also a net food exporting country.

The past strategies do not explicitly recognize the need to raise farmer's income and did not mention any direct measure to promote farmers welfare. In many cases farmer's income did not grow much with increase in output. 
Farmer's income remained low, which is evident from incidence of poverty among farm household. With all these past experiences, there is need to focus on factors which accelerate the income of farmers. Therefore Government of India has initiated a novel initiative for doubling farmer's income by 2022. The pathway for doubling of farmers' income includes several dimensions, from production to post-harvest management. The plan should include; bridging yield gap, crop diversification, improvement in total factor productivity and proper management of irrigation (Birthal, et al., 2007; Chand, et al., 2011) along with the provision of market and institutional support for efficient post-harvest management (Saxena, and Chand, 2017). Therefore, strong measures will be needed to harness all possible sources of growth in farmer's income within as well outside agriculture sector. In the same line Krishi Vigyan Kendra, Banda has adopted Jakhani village for fulfilling the dream of Hon'ble Prime minister of India, Shri Narendra Modiji with the objective to double the farmer's income by 2022 .

\section{Materials and Methods}

The present study was undertaken at Krishi Vigyan Kendra, Banda, Uttar Pradesh where Jakhani village has been selected for doubling farmers income. A total of 50 respondents were selected randomly who were engaged in agriculture and allied activities. Data were collected through focus group discussion, Participatory Rural Appraisal tools and a semi-structured interview schedule.

The problem identification technique was used to identify and prioritize the problems related to agriculture and allied sectors in Jakhani village. For this purpose, around 50 farmers was asked to list their major problems related to agriculture and allied sector then 30 farmers randomly were asked to rank based on their severity of economic losses. As a result eight main problems were listed down and Rank based Quotient (RBQ) method was used for ranking the most important and severe problem.

$$
R B Q=\sum f_{i}(n+1-i) / M \times n \times 100
$$

Where,

$$
\begin{array}{lll}
\mathrm{f}_{\mathrm{i}} & = & \begin{array}{l}
\text { Number of respondents } \\
\text { reporting a particular problem } \\
\text { under } \mathrm{i}^{\text {th }} \text { rank }
\end{array} \\
\mathrm{M} & = & \text { Number of respondents } \\
\mathrm{n} & = & \text { Number of problems } \\
\mathrm{i} & = & \text { Rank of problem }
\end{array}
$$

\section{Results and Discussion}

It is clearly evident from Table 1 that nearly half of the respondents (46.00\%) were belongs to old aged category followed by middle aged and young age category. Only 12.00 per cent of the respondents were female, rest $(88.00 \%)$ were the male. Nearly equal percentage of respondents was found to have formal education upto secondary $(24.00 \%)$ and higher secondary $(30.00 \%)$. Majority of respondent were $(66.00 \%)$ were having high category of experience followed by medium level of experience $(26.00 \%)$ and low $(8.00 \%)$ level of experience category. Majority of respondents $(74.00 \%)$ were living in nuclear family whereas 26.00 per cent were living in joint family. Majority of respondents $(54.00 \%)$ belongs to low category of annual income.

\section{Problem identification and prioritization}

A list of problems have been listed and prioritized according their RBQ value and result were presented in Table 2 which indicated that crop losses due to Anna pratha was prioritized as most severe problem in village with RBQ value (94.59). It was reported during interactions with respondents that farmers leave their cows and make them 
stray animals as they were less productive. Hence breed improvement programmes should be implemented and farmers should motivate to use cow dung and urine for organic farming.

Second most prioritized problems was getting less price for their produce (Pusa Basmati1121) with RBQ value (90.41). It was found that nearly $95.00 \%$ of farmers of village were growing Pusa Basmati-1121 rice in Kharif season but they were not getting fair price for their produce. Farmers were hardly getting Rs. 2800 to 3000 per Qt. It was suggested that marketing structure should be opened especially for Basmati rice and mini rice mill also can be open for basmati rice that can play good role for doubling farmers income. Moreover farmers should also motivate to use National Agriculture Market (e-NAM) and Farmer Producer Organisation (FPO) platform for marketing of their farm produce to fetch better price.

The finding was in line with findings of Kumar et al., (2016) who reported that poor access to market was the important problem faced by the farmers in adoption of mitigation and adaptation of climate change practices in agriculture in Madhya Pradesh.

Table.1 Socio-economic profile of respondents $(\mathrm{n}=50)$

\begin{tabular}{|c|c|c|c|c|}
\hline S. no. & Variables & Categories & Frequency & Percentage \\
\hline \multirow[t]{3}{*}{1} & \multirow[t]{3}{*}{ Age } & Young (upto 35 Years) & 11 & 22.00 \\
\hline & & Middle aged (36-50 years) & 16 & 32.00 \\
\hline & & Old aged ( $>50$ Years $)$ & 23 & 46.00 \\
\hline \multirow[t]{2}{*}{2} & \multirow[t]{2}{*}{ Gender } & Male & 44 & 88.00 \\
\hline & & Female & 6 & 12.00 \\
\hline \multirow[t]{6}{*}{3} & \multirow[t]{6}{*}{ Education } & Illiterate & 6 & 12.00 \\
\hline & & Primary & 8 & 16.00 \\
\hline & & Middle & 11 & 22.00 \\
\hline & & Secondary & 12 & 24.00 \\
\hline & & Higher Secondary & 15 & 30.00 \\
\hline & & Graduate and above & 8 & 16.00 \\
\hline \multirow[t]{3}{*}{4} & \multirow[t]{3}{*}{ Experience } & Low (<5 years) & 4 & 8.00 \\
\hline & & Medium (5-10 years) & 13 & 26.00 \\
\hline & & High (>10 years) & 33 & 66.00 \\
\hline \multirow[t]{3}{*}{5} & \multirow[t]{3}{*}{ Family size } & Low $(<5)$ & 11 & 22.00 \\
\hline & & Medium (5-8) & 23 & 46.00 \\
\hline & & High $(>8)$ & 16 & 32.00 \\
\hline \multirow[t]{2}{*}{6} & \multirow[t]{2}{*}{ Family type } & Nuclear & 37 & 74.00 \\
\hline & & Joint & 13 & 26.00 \\
\hline \multirow[t]{3}{*}{7} & \multirow[t]{3}{*}{ Annual income } & Low (< Rs. 50,000) & 27 & 54.00 \\
\hline & & $\begin{array}{c}\text { Medium (Rs. 50,000-Rs. } \\
1,00,000)\end{array}$ & 14 & 28.00 \\
\hline & & High (>Rs. $1,00,000)$ & 9 & 18.00 \\
\hline
\end{tabular}


Table.2 Problems identified in Jakhani village based on RBQ value $(n=30)$

\begin{tabular}{|l|c|c|}
\hline \multicolumn{1}{|c|}{ Problem } & RBQ Value & Rank \\
\hline Crop losses due to Anna pratha & 94.59 & I \\
\hline Getting less price for their produce (Pusa basmati-1121) & 90.41 & II \\
\hline Poor yield of major crops (Rice and wsheat) & 71.66 & III \\
\hline Disease infestation in dairy animals & 53.34 & V \\
\hline Limited availability of agricultural inputs & 36.25 & VI \\
\hline Unawareness about the alternate source of income & 23.75 & VII \\
\hline Low milk yield of dairy animals & 69.99 & IV \\
\hline Migration of farmers from agriculture & 21.67 & VIII \\
\hline
\end{tabular}

Third most important problems was poor yield of major crops. The area has rice- wheat cropping system and the yield of major crops was found less as the farmers were less aware of scientific package of practices of major crop. Late sowing of crops, less use of fertilizer, less availability of irrigation facilities, terminal heat in wheat might be the important causes of poor yield of major crops.

The fourth most prioritized problems was low milk yield of dairy animals with RBQ value (69.99) it was reported that most of the respondents were having non-descript cows which were having less milk productivity which was reported 0.5-1 litres of milk/day.

The disease infestation among dairy animals was fifth prioritized problems of farmers of Jakhani village. As it was reported that animals were severely affected by Foot and mouth disease and Haemorrhagic septicaemia.

Therefore mass vaccination programme should be carried out by the department of Animal Husbandry. Limited availability of agricultural inputs was the sixth most prioritized problems of respondents as it was reported that various agricultural inputs which includes seeds, fertilizers etc. were less available to the farmers at primary agricultural credit society. Unawareness about the alternate source of income and migration of farmers from agriculture were also the important problems faced by the farmers of Jakhani village.

The study concluded that, crop losses due to Anna pratha, getting less price for their produce (Pusa Basmati-1121) and poor yield of major crops (Rice and wheat) were the most prioritized problems of farmers, therefore the policy makers of state animal husbandry department can prepare plan for breed improvement and also promote organic farming by use of cow dung and urine.

Farmers should be motivated to use National Agriculture Market (e-NAM) and Farmer Producer Organisation (FPO) platform for marketing of their farm produce to fetch better price. Timely sowing, judicial use of fertilizer and appropriate use of planting and agro techniques should be used for getting better yield of major crops.

\section{Acknowledgement}

The authors acknowledged Directorate of Extension, BUAT, Banda and Director ICARATARI, Kanpur for providing facilities and guidance to carry out the work. 


\section{References}

Birthal, P.S.; Joshi, P.K.; Roy, D. and Thorat, A. (2007). Diversification in Indian Agriculture towards High Value Crops: The Role of Smallholders. IFPRI Discussion Paper 00727, International Food Policy Research Institute, Washington, D.C.

Chand, R.; Kumar, P. and Kumar, S. (2011). Total Factor Productivity and Contribution of Research Investment to Agricultural Growth in India. Policy Paper 25. National Centre for Agricultural Economics and Policy Research, New Delhi.

Government of India. (2019).Press
Information Bureau, Ministry of Finance, Government of India.

Kumar, M.P.; Singh, R.J.; Pandey, D.K.; Singh, R.; Jadav, N.B. and Rajput, R.P. (2016). Problems faced by the farmers in adoption of mitigation and adaptation of climate change practices in agriculture. International Journal of Agriculture Sciences, 8(56): 3086-3088.

Saxena, R. and Chand, R. (2017). Understanding the Recurring Onion Price Crisis: Revelations from Production-Trade-Price Linkages. Policy Paper (Forthcoming). Agricultural Economics and Policy Research (NIAP), New Delhi

\section{How to cite this article:}

Diksha Patel, Shyam Singh, S. C. Singh and Manjul Pandey. 2020. Problems Identification of DFI Village Jakhani: A Participatory Approach. Int.J.Curr.Microbiol.App.Sci. 9(05): 353-357. doi: https://doi.org/10.20546/ijcmas.2020.905.039 